\title{
Is There A Double Dividend From Classroom Experimental Games?
}

Panagiotis Tsigaris, Thompson Rivers University, Canada

\begin{abstract}
This paper provides evidence indicating that experimental games can trigger a double dividend. The dividend, measured in terms of enhanced performance, accrues to both the students and to the instructor. The evidence for the instructor's dividend is obtained from evaluation questionnaires administered in an introductory microeconomics course at Thompson Rivers University (TRU) during the Fall 2006 where seven experimental classroom games were conducted to illustrate economic concepts. The evidence for the students' dividend is obtained from examining marginal and absolute performance in two quizzes administered in the same course. We also find evidence that supports Fels earlier conjecture that the intensity of the games played is an important element for the enhancement of a student's performance.
\end{abstract}

Keywords: Active learning methods, classroom experimental games, effectiveness of games

\section{INTRODUCTION}

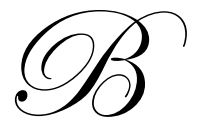

ecker and Watts (1996, 2001, and 2005) have tracked a large sample of U.S. academic economists' teaching practices over the last decade. They found the dominant teaching style to be traditional standard lectures known as "chalk and talk". The median respondent surveyed in 2005 spent 83 percent of the lecture time talking and using chalk. In the more recent paper they conclude, that there are signs of change towards more active learning methods especially from younger economists.

Brauer and Delemeester (2001) point to a number of benefits that accrue to the instructor from using experimental classroom games such as break from routine, motivation, fun and reputation of economics. ${ }^{1}$ One of the most important benefits to the instructor is improvement in teaching which can lead to tenure and hence job security as well as promotion. The experimental approach can also have spill-over effects on research activity.

Is there a dividend to the instructor of running classroom games and how is it captured? The evidence is obtained from evaluation questionnaires administered in an introductory microeconomics course at Thompson Rivers University (TRU) during the Fall 2006 where seven experimental classroom games were conducted to illustrate economic concepts. Becker (1997) suggested that instructor success is judged by student evaluation questionnaire given at the end of the semester. ${ }^{2}$ Even though one might argue that higher expected grades leads to more favourable student evaluations and thus a positive correlation between teaching evaluations and student grades, the empirical evidence is mixed on this front. ${ }^{3}$ Causation could be the opposite way, namely increased performance of the instructor can lead to higher grades for students. ${ }^{4}$

Turning to the second dividend, there is a general agreement that experimental classroom games aid students' learning for a number of reasons (Holt (2003)). Economic theories can be verified using the results from the experiments. Illustrating concepts using student's created data is more effective in learning and more fun than relying on textbook examples. Finally, to the extent that experimental classroom games affect performance, this may have a spill-over effect on a student's performance in other courses (Brauer and Delemeester (2001)). From a student perspective, the benefits of games are usually measured in terms improved student performance in exams relative to the status quo of some controlled environment. 
A testing procedure to examine the value-added of games is to conduct a pre-course and post-course test in both experimental and non-experimental classrooms. Dickie (2006) and Emerson and Taylor (2004)) indicate that experimental games tend to increase the students understanding of economics relative to traditional methods of teaching economics.

In this research we compare the performance of the students in two quizzes. The first quiz was conducted after playing one experiment and it involved topics such as introduction to economics and markets (i.e., demand and supply concepts). The second quiz was conducted after playing three games and it involved public policy issues such as externalities (i.e., pollution problems), government regulations (i.e, rent controls and minimum wages), efficiency and fairness issues, taxes, and public good provision (i.e., clean air). Both quizzes had 10 multiple choice questions with a time limit of 10 minutes of classroom time. ${ }^{5}$ This paper also investigates as to whether performance is affected by the number of games students played after controlling for a number of factors. It also investigates Fels (1993) hypothesis that a single experiment will not affect student performance but using a number of experiments over a period makes a difference in students' performance. ${ }^{6}$

In conclusion, this paper attempts to provide evidence that experimental games can trigger a double dividend. The dividend, measured in terms of enhanced performance, can accrue to both the student and to the instructor.

\section{THE SETTING, GAMES PLAYED AND STUDENTS' PERCEPTION}

Seven classroom games were played in an introductory microeconomics classroom during the Fall 2006 semester at TRU. ${ }^{7}$ Students played a pit market game to illustrate the concept of convergence to market equilibrium, the ultimatum game to illustrate bargaining and fairness issues, a paper river game to illustrate externalities and property rights, the $M \& M$ game to illustrate problems with common ownership of resources, a fund raising game to illustrate under provision of public goods and free riders, the production of widgets in order to illustrate productivity changes from division and specialization of work as well as from the law of diminishing returns, and an oligopoly game to illustrate problems with collusions. Table 1 below summarizes the games played:

The table show chronologically the games, their objectives, the location, the time to play, and participation rates. Participation in a game guaranteed two marks as a reward except for the last two games where only a small number of students participated in the experiment. In some games rewards were also connected to the earnings. Some games were announced ahead of time while other games were held without warning.

The classroom size was relatively large for TRU. There were 55 students enrolled in the course. Approximately 45 percent were female students. Seventy-three percent were business students, another 18 percent were tourism students, 5 percent from arts and 4 percent from sciences. Twenty-seven percent of the total students were international. Sixty-four percent were first year students and another 22 percent were second year students. Some of the games were played during the seminar and others during class time.

Students' perception of the games were retrieved from two sources; from the institutional evaluation form and from a survey conducted close to the end of the semester. The survey results indicate that students found that the experiments increased their understanding of economic concepts (mean $4=$ agree). They also found helpful the instructor's presentation of the results of the experimental games (mean $4=$ agree). The following are some quotes of students' perception of the games in the written section of the evaluation form where they were asked for "any other comments about your learning experience in this class."

- I am finding the classroom experiments are a very useful and practical way to help me understand the lesson material.

- $\quad$ The games we play are very helpful in explaining courses content

- $\quad$ The experiments made the class very fun.

- $\quad$ I enjoyed eating smarties. 
Table 1: The Games Played in Classroom/Seminar

\begin{tabular}{|c|c|c|c|c|}
\hline Games Played & Objective of Game & Place/Time & Participation & Rewards \\
\hline $\begin{array}{l}\text { The pit market game } \\
\text { developed by Holt } \\
\text { (1996). }\end{array}$ & $\begin{array}{l}\text { To illustrate the } \\
\text { convergence and efficiency } \\
\text { of the competitive market. }\end{array}$ & $\begin{array}{l}\text { In the three seminars: } \\
50 \text { minutes each. } \\
\text { Results presented in } \\
\text { classroom. }\end{array}$ & $\begin{array}{l}\text { Participation rate: } \\
86 \text { percent }\end{array}$ & $\begin{array}{l}\text { Reward to the buy } \\
\text { and seller student } \\
\text { with highest earnings }\end{array}$ \\
\hline $\begin{array}{l}\text { A variation of the } \\
\text { bargaining game } \\
\text { developed by } \\
\text { Dickinson (2002) }\end{array}$ & $\begin{array}{l}\text { To illustrate bargaining and } \\
\text { fairness issues. }\end{array}$ & $\begin{array}{l}\text { Lecture time for one } \\
\text { round: } 20 \text { minutes. } \\
\text { Two rounds played. }\end{array}$ & $\begin{array}{l}\text { Participation rate: } \\
82 \text { percent }\end{array}$ & $\begin{array}{l}\text { No reward other than } \\
\text { that of participation. }\end{array}$ \\
\hline $\begin{array}{l}\text { The paper river } \\
\text { developed by Hoyt, } \\
\text { Ryan and Houston } \\
\text { (1999) }\end{array}$ & $\begin{array}{l}\text { Illustrates a negative } \\
\text { externality (pollution) and } \\
\text { Coase's Theorem to solve } \\
\text { the problem by assigning } \\
\text { property rights. }\end{array}$ & $\begin{array}{l}\text { In the three seminars: } \\
50 \text { minutes in each } \\
\text { seminar. } \\
\text { Results presented in } \\
\text { the following } \\
\text { seminar. }\end{array}$ & $\begin{array}{l}\text { Participation rate: } \\
64 \text { percent }^{9}\end{array}$ & $\begin{array}{l}\text { No reward other than } \\
\text { that of participation }\end{array}$ \\
\hline $\begin{array}{l}\text { The free rider game } \\
\text { developed by Sulock } \\
(1990)\end{array}$ & $\begin{array}{l}\text { To illustrate that there is } \\
\text { under-provision of the } \\
\text { public good (i.e. } \\
\text { contributions) due to the } \\
\text { free rider problem. }\end{array}$ & $\begin{array}{l}\text { Lecture time: } 15 \\
\text { minutes. } \\
\text { Results presented in } \\
\text { the following } \\
\text { seminar. } \\
\text { Two rounds were } \\
\text { played. }^{10}\end{array}$ & $\begin{array}{l}\text { Participation rate: } \\
82 \text { percent }\end{array}$ & $\begin{array}{l}\text { Reward initially } \\
\text { promised according } \\
\text { to earnings but then } \\
\text { removed due to } \\
\text { distributional issues. }\end{array}$ \\
\hline $\begin{array}{l}\text { Common ownership of } \\
\text { an M\&M plate } \\
\text { developed by Hazlett } \\
\text { (1997) }\end{array}$ & $\begin{array}{l}\text { To illustrate the over- } \\
\text { harvesting tendencies of a } \\
\text { common-property resource }\end{array}$ & Lecture: 20 minutes. & $\begin{array}{l}\text { Participation rate: } \\
84 \text { percent }\end{array}$ & $\begin{array}{l}\text { Reward of M\&Ms } \\
\text { harvested. }\end{array}$ \\
\hline $\begin{array}{l}\text { Production of widgets } \\
\text { in the Classroom } \\
\text { developed by Neral } \\
\text { (1993) }\end{array}$ & $\begin{array}{l}\text { To illustrate division and } \\
\text { specialization of labor and } \\
\text { the law of diminishing } \\
\text { returns. }\end{array}$ & Lecture: 15 minutes & $\begin{array}{l}3 \text { students selected } \\
\text { on a volunteered } \\
\text { basis }\end{array}$ & $\begin{array}{l}\text { Reward of M\&Ms } \\
\text { for each student. }\end{array}$ \\
\hline $\begin{array}{l}\text { Oligopoly game } \\
\text { developed by } \\
\text { Hemenway, Moore, } \\
\text { and Whitney (1987) }\end{array}$ & $\begin{array}{l}\text { To illustrate difficulties } \\
\text { involved in collusive } \\
\text { behaviour. }\end{array}$ & Lecture: 10 minutes & $\begin{array}{l}2 \text { students selected } \\
\text { on a volunteered } \\
\text { basis }\end{array}$ & $\begin{array}{l}\text { Reward the payoff } \\
\text { amounts in the game. }\end{array}$ \\
\hline
\end{tabular}

\section{INSTRUCTOR'S PERFORMANCE: THE FIRST DIVIDEND}

Instructors at TRU are evaluated by students on a regular basis. The evaluations are formative taking place every year on a selected set of courses that is determined by the instructor or summative, taking place every five years. The evaluation form is filled anonymously by the students and the results are given to the instructor after the course is over. The objective of the evaluation is to examine the instructor's performance in three main skill areas; presentational, organizational and interpersonal skills. Within each skill/category there are subcategories. The presentational skills consist of the following sub-categories: explains material, demonstrates knowledge, answers clearly, demonstrates enthusiasm, listens to students, prepared for class, summarizes material usefully, uses class time effectively, and communicates effectively. The organizational skills consist of the following: graded work within reasonable time, evaluates fairly, available for consultation, course well organized, provides appropriate feedback, explains grading, follows the outline, assignments relevant, and relevant exams. The interpersonal skills are broken down to that of being helpful, treating students with respect, encouraging questions and being approachable. The score is structured such that a $5=$ Almost always, $4=$ frequently, $3=$ sometimes, $2=$ occasionally, $1=$ hardly ever. Thus a score of 5 indicates that the student strongly agrees, while a score of one indicates that the student strongly disagrees. The higher the score the better the instructor's teaching performance in the related categories. TRU requires an average score of 3.5 or higher to be considered acceptable performance for these categories. 
In what follows evidence is provided of a change in the instructor's performance from adding the experimental methods as a teaching method to the traditional style of teaching. The instructor began teaching as a graduate student at Concordia University in Montreal. Initially chalk and talk was the dominant teaching method used. Through time there has been an increased usage of technology such as power point slides, as well as the usage and analysis via statistical software of real life data to illustrate statistical concepts and macroeconomics facts. Experimental games were not used in the previous courses. Courses at the first year were taught the traditional way of chalk and talk, while upper level courses had more student-instructor interaction and applied projects. Courses at the first year had larger size classes (36-60) than upper level courses which range from a low of five to thirty six students.

The evaluation questionnaire from the principles of microeconomics course (ECON 190) where experiments were part of the course is compared to his previous performance. The absence of experimental games in the past as the teaching method makes these evaluations a controlled environment. Table 2 provides the instructor's historical performance at TRU from 1993 until winter of 2006 from thirty nine course evaluations in economics. ${ }^{11}$

Table 2: Overall Statistics on the Instructor's Performance from $1993-2006$ at TRU. ${ }^{12}$

\begin{tabular}{|c|c|c|c|c|}
\hline Statistics & Presentational Skills & Organizational Skills & Interpersonal Skills & Overall Performance \\
\hline Average & 4.01 & 4.15 & 4.17 & 4.11 \\
\hline Minimum & 3.49 & 3.67 & 3.96 & 3.61 \\
\hline Maximum & 4.48 & 4.55 & 4.59 & 4.53 \\
\hline Standard Deviation & 0.2394 & 0.1913 & 0.2349 & 0.2083 \\
\hline Stdev. For mean & 0.0383 & 0.0306 & 0.0376 & 0.0334 \\
\hline 95 \% CI for mean & $(3.94,4.09)$ & $(4.08,4.21)$ & $(4.09,4.25)$ & $(4.04,4.18)$ \\
\hline
\end{tabular}

Figure 1 shows the presentational skills over time indicating no apparent upward trend over the years. The mean response is around the value of 4 .

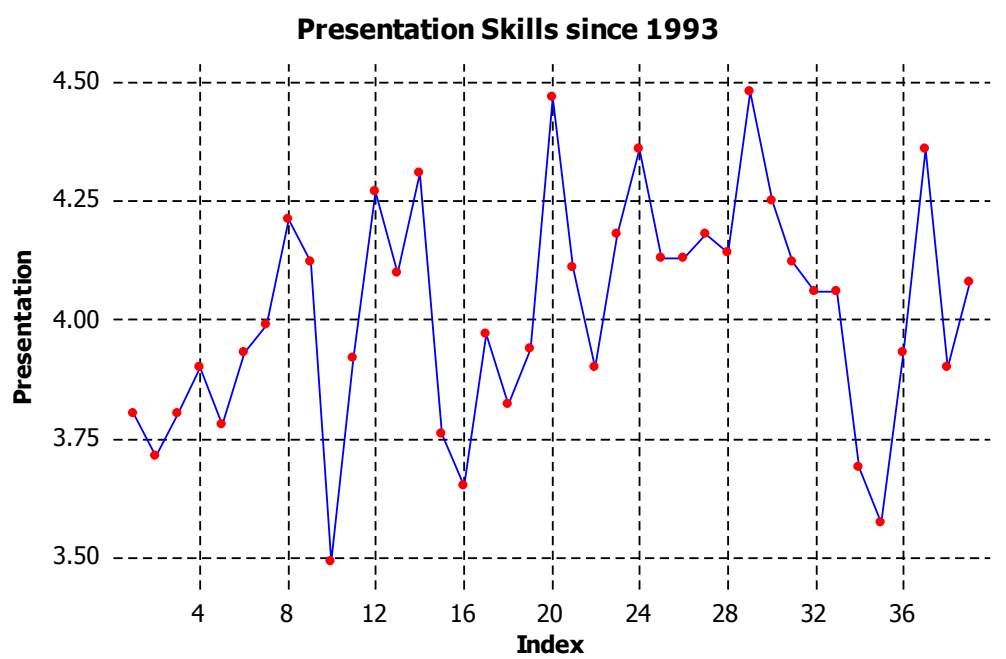

Figure 1: Presentational skills since 1993 (Doesn't include this course). 
Table 3: Average performance in various course categories

\begin{tabular}{|l|c|c|c|c|c|}
\hline Breakdown of Courses & $\#$ & $\begin{array}{c}\text { Presentation } \\
\text { Skills }\end{array}$ & $\begin{array}{c}\text { Organization } \\
\text { Skills }\end{array}$ & $\begin{array}{c}\text { Interpersonal } \\
\text { Skills }\end{array}$ & $\begin{array}{c}\text { Overall } \\
\text { Performance }\end{array}$ \\
\hline Econ 190 courses & 5 & 3.87 & 4.06 & 4.00 & 3.98 \\
\hline $1^{\text {st }}$ year courses & 8 & 3.89 & 4.05 & 3.99 & 3.98 \\
\hline $1^{\text {st }} \& 2^{\text {nd }}$ year courses & 15 & 3.92 & 4.06 & 4.04 & 4.00 \\
\hline All courses except 4th year & 26 & 3.98 & 4.10 & 4.11 & 4.06 \\
\hline $4^{\text {th }}$ year courses & 9 & 4.17 & 4.26 & 4.39 & 4.27 \\
\hline Course evaluations in 1993-94 & 6 & 3.82 & 3.98 & 3.92 & 3.91 \\
\hline Course evaluations since 2000 & 13 & 4.06 & 4.22 & 4.23 & 4.17 \\
\hline Since 2000 excluding 4th year & 8 & 3.99 & 4.17 & 4.14 & 4.10 \\
\hline
\end{tabular}

Note: The course evaluations in 1993-94 are all at the $1^{\text {st }}$ year.

Table 3 indicates that the average performance in each of the three categories is around a score of four. Lower level economics courses have a lower average score than the upper level courses. This is a reflection of larger class sizes in lower level courses and also students in lower levels are not as interested as the students that specialize in economics. Thus comparisons should be handled with care since different courses represent a different population statistics. In addition, there seems to be a mild (statistically insignificant) upward trend in teaching performance relative to the first two years at TRU which is indicative of experience.

Table 4 second row shows the instructors performance in the Principles of Microeconomics course (Econ 190) in the Fall 2006 where the experimental game methods were added to the class. Comparing the instructor's performance with and without experimental games is thus feasible. The scores in the presentational, organizational, and interpersonal skill are the highest that was ever achieved when compared to all $1^{\text {st }}$ and $2^{\text {nd }}$ year courses. The organizational skills score is the highest against all lower and upper level courses taught in the past.

Table 4: Teaching Evaluation Results from the Experimental Classroom

\begin{tabular}{|c|c|c|c|c|}
\hline Course & Presentation Skills & Organization Skills & $\begin{array}{c}\text { Interpersonal } \\
\text { Skills }\end{array}$ & $\begin{array}{c}\text { Overall } \\
\text { Performance }\end{array}$ \\
\hline Econ 190 course in fall 2006 & 4.42 & 4.60 & 4.41 & 4.48 \\
\hline
\end{tabular}

The probability of observing an event as extreme or more is computed using the standardized normal random variable is:

$$
\mathrm{z}_{1}=\frac{\mathrm{x}_{1}-\mu}{\sigma} \rightarrow \mathrm{N}(0,1)
$$

Where $\mathrm{x}$ is the observed score, $\mu$ is the population mean and $\sigma$ is the population standard deviation. The higher the standardized variable in absolute terms the further away the observation is from the population mean score. Hence the probability and the frequency of the event happening is low. Figure 2 confirms that the probability is low by showing the histogram for organizational skills. The observed organizational skills score from the experimental games course lies in the extreme right of the distribution coloured as a black bar.

The probability of observing a standardized score as extreme or more extreme than the one observed with the experimental classroom games course is computed as $\mathrm{p}\left(\mathrm{z} \geq \mathrm{z}_{1}\right)$. For the population mean value and for the standard deviation usage of the historical mean values was employed. Table 5 shows the probability of observing a score as high or higher, as the one in the experimental class during the fall 2006 , due to random chance in $1^{\text {st }}$ and $2^{\text {nd }}$ year courses. The probability is very small. This might be due to chance or there might be due to a shift in the mean of the distribution to a higher level. 


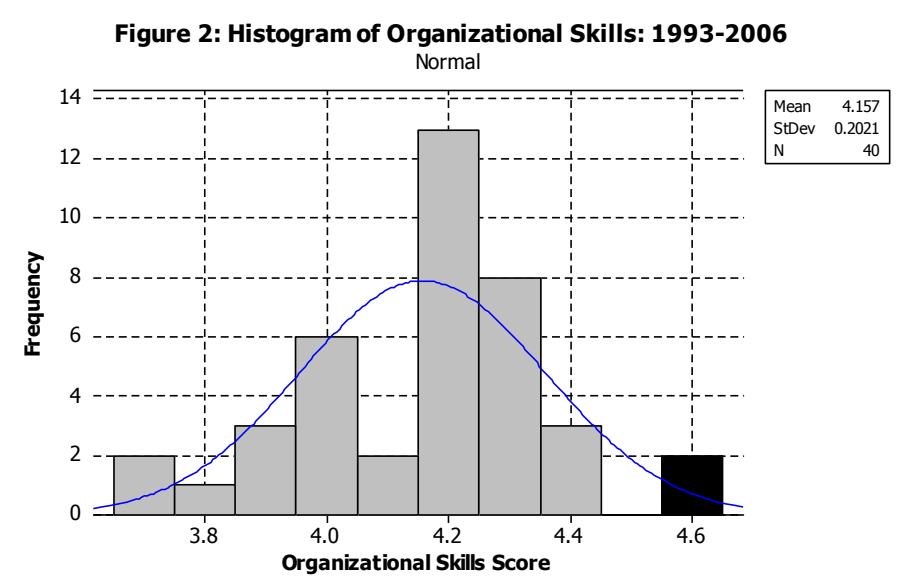

Table 5: Probability of Event Occurring as Extreme or More by Random change

\begin{tabular}{|l|c|c|c|c|}
\hline Breakdown of Courses & $\begin{array}{c}\text { Presentation } \\
\text { Skills }\end{array}$ & $\begin{array}{c}\text { Organization } \\
\text { Skills }\end{array}$ & $\begin{array}{c}\text { Interpersonal } \\
\text { Skills }\end{array}$ & $\begin{array}{c}\text { Overall } \\
\text { Performance }\end{array}$ \\
\hline Econ 190 course in fall 2006 & 4.42 & 4.60 & 4.41 & 4.48 \\
\hline Probability of Observing Event as Extreme or More Extreme \\
\hline Econ 190 courses in past (5) & 0.013 & 0.018 & 0.031 & 0.017 \\
\hline $1^{\text {st }}$ year courses & 0.004 & 0.004 & 0.015 & 0.005 \\
\hline $1^{\text {st } \& 2^{\text {nd }} \text { year courses }}$ & 0.017 & 0.005 & 0.037 & 0.009 \\
\hline
\end{tabular}

In conclusion, the evaluation forms indicate a marked increase performance in the instructor's organizational, presentational, interpersonal and overall skills relative to his historical pattern which is used as a controlled environment. In the next section we explore the second dividend, namely improved student's performance.

\section{STUDENTS PERFORMANCE: THE SECOND DIVIDEND}

In order to determine the impact of participating in classroom games we compare the performance of the students in two quizzes. As stated in the introduction, the first quiz was conducted after playing one experiment and it involved topics such as introduction to economics and markets (i.e., demand and supply). The second quiz was conducted after playing three games and it involved topics such as negative externalities (i.e., pollution problems), government regulations, efficiency and fairness issues, taxes, and public goods provision. Both quizzes had 10 multiple choice questions with a time limit of 10 minutes of classroom time. In the first quiz the average score was 65 percent, while in the second quiz the average score was 72 percent. Figure 3 shows the differences in the performance of students in the two quizzes. Seven students did much worse than their first quiz, another ten students did slightly worse relative to the first quiz, nine students did just as well, while twenty eight students performed better in the second quiz relative to the first quiz. Is the average differences between the two quizzes statistically significant different from zero? Conducting a paired difference test to examine the null hypothesis that there is no difference in population mean values between the two tests results in rejecting the null hypothesis in favour of the alternative hypothesis that the population mean value of the $2^{\text {nd }}$ quiz is greater than the $1^{\text {st }}$ quiz. Table 6 shows the details of the test. 


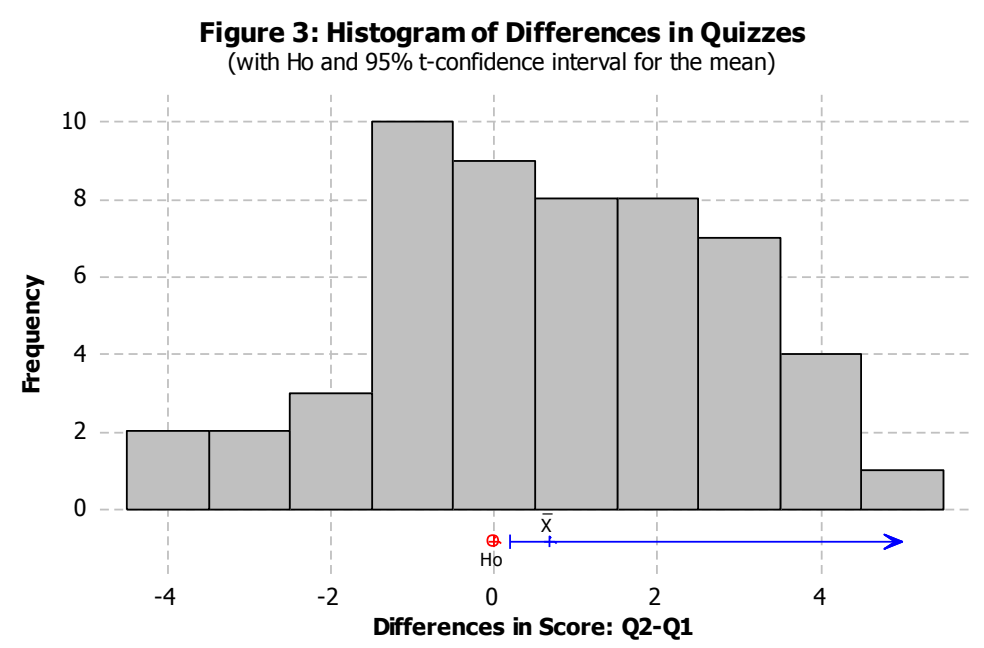

Table 6: Paired difference test between quiz 1 and $2^{\text {nd }}$ quiz

\begin{tabular}{|c|c|c|c|}
\hline & Mean & StDev & SE Mean \\
\hline Quiz 2 & 7.167 & 1.788 & 0.2434 \\
\hline Quiz 1 & 6.500 & 1.950 & 0.2653 \\
\hline Difference & 0.667 & 2.128 & 0.2896 \\
\hline Observations: 54 & & & \\
\hline \multicolumn{4}{|c|}{ 95\% level bound for mean difference: 0.18187} \\
\hline
\end{tabular}

What is causing this increased performance? One explanation is that there were more experiments conducted between the 1 st and $2^{\text {nd }}$ quiz. This increased usage of games and participation motivated students to study more or it aided them in understanding the concepts showing an increase in performance. Another explanation could be the second quiz was easier relative to the first all else being equal. However, the latter explanation lacks credibility since the quizzes were similarly structured (i.e., 10 multiple choice questions from the same test bank with the same 10 minutes time limit and degree of difficulty). ${ }^{13}$ Another reason could be that students were more interested in the public policy issues and less with the introductory material of the course. ${ }^{14}$ Here we focus on measuring the impact of the first explanation on performance. Did the experiments have any influence on performance?

In order to provide additional insight towards explaining the performance quiz is to conjecture that the score of a quiz depends on the number of games played, the student's cumulative GPA to control for student ability and study habits, gender, residency status and program of study. Accordingly, one can assume that the following system of equations describes the system:

$$
\begin{aligned}
& \mathrm{S}_{1 \mathrm{i}}=\alpha_{\mathrm{o}}+\alpha_{1} \mathrm{G}_{1 \mathrm{i}}+\alpha_{2} \operatorname{CGPA}_{\mathrm{i}}+\alpha_{3} \text { Gender }_{\mathrm{i}}+\alpha_{4} \operatorname{Progam}_{\mathrm{i}}+\alpha_{5} \operatorname{Dom}_{\mathrm{i}}+\mathrm{u}_{1 \mathrm{i}} \\
& \mathrm{S}_{2 \mathrm{i}}=\beta_{0}+\beta_{1} \mathrm{G}_{2 \mathrm{i}}+\beta_{2} \operatorname{CGPA}_{\mathrm{i}}+\beta_{3} \operatorname{Gender}_{\mathrm{i}}+\beta_{4} \operatorname{Progam}_{\mathrm{i}}+\beta_{5} \operatorname{Dom}_{\mathrm{i}}+\mathrm{u}_{2 \mathrm{i}}
\end{aligned}
$$


where, $S_{1 i}, S_{2 i}$ are the scores in the first and second quiz respectively (range: 0-10); $G_{1 i}$ represents a dummy variable taking the value of 1 if the ith student was present in first experimental game, 0 otherwise; $G_{2 i}$ represents the number of games the ith student played between the second and first quiz (i.e., values of $0,1,2$, and 3); CGPA $_{i}$ is the cumulative GPA of the student (Range: 0-4.33); Gender ${ }_{i}$ takes the value of 1 if student is a female, 0 if male; Program ${ }_{i}$ takes the value of 1 if student is enrolled in the business program, 0 otherwise; and Dom $_{i}$ takes the value of 1 if student is domestic, 0 if international. Each error term $u_{1 i}, u_{2 i}$ is assumed to be independently and identically randomly distributed with mean zero. The error terms across equations most probably are not independent since variables such as study time, relative performance of students (i.e., students trying to improve in second quiz given their unexpected lower in the first quiz), and uncertainty is omitted. Thus the OLS method might yield inefficient estimated parameters. In order to get more precise estimates we use the seemingly unrelated system equations method (SUR) developed by Zellner to estimate the parameters. ${ }^{15}$ If Fels' conjecture is correct then a single experiment will not affect student performance and we would expect $\alpha_{1}=0$. However, using a number of experiments over a period might make a difference in students' performance. Thus for the second equation above we expect to find $\beta_{1}>0$. Cumulative GPA is expected to affect performance positively ( $\alpha_{2}>0$ and $\beta_{2}>0$ ) since it captures a student's overall ability and study habits. We do not have priors for the signs of the other three control variables. ${ }^{16}$

Table 7 columns 2 and 3 present the results from this estimation. The number of games played between quiz 2 and 1 affects performance positively. However, as expected this is not the case with the first quiz. The results confirm Fels' conjecture about the frequency of games being important in affecting performance. A student's cumulative GPA is also important in affecting test performance for both quizzes indicating that a student's ability or study habits are important variables in determining performance. ${ }^{17}$ On average, female students performed worse in the first quiz relative to male students, however this is not the case in the second quiz where gender is irrelevant in determining performance. Furthermore, it did not matter if the student was domestic or international in affecting performance in each of the two quizzes. Business students did on average better in the first quiz relative to tourism, arts and science students but this was not the case for the second quiz where program of study was not a significant variable.

Further to determining the impact of the games on the level of quiz performance we are also interested to determine the factors that influence marginal performance, a measure of increased productivity, $\mathrm{S}_{2 \mathrm{i}}-\mathrm{S}_{1 \mathrm{i}}$. One of the factors that might influence marginal productivity is the number of games a student played between the $2^{\text {nd }}$ and the $1^{\text {st }}$ first quiz as mentioned previously. ${ }^{18}$ The results in column 4 of table 6 indicate the expected difference in scores depends positively on the attendance of classroom games. The higher the attendance of classroom games, the higher the performance in the second quiz relative to the first quiz. How higher? The results indicate that approximately one additional grade point difference (one additional correct multiple choice question) will be earned for every one additional classroom game attendance on average. ${ }^{19}$ The absence of a measure of increased study time prior to the writing of the quiz relative to the study time allocated to the first quiz is a problem in that experimental games may not be the cause of increased performance but the increased study time. Thus we cannot conclude that the experimental games are the direct cause of increased performance since marginal increase in study time is not accounted for.

However, the experimental games could have triggered an increase in study time which triggered an increase in performance. One can conclude that the increased game attendance causes a direct or indirect, through increase in study time, increase in performance. ${ }^{20}$ Figure 4 indicates the pattern of marginal performance and number of games played between the quizzes. 


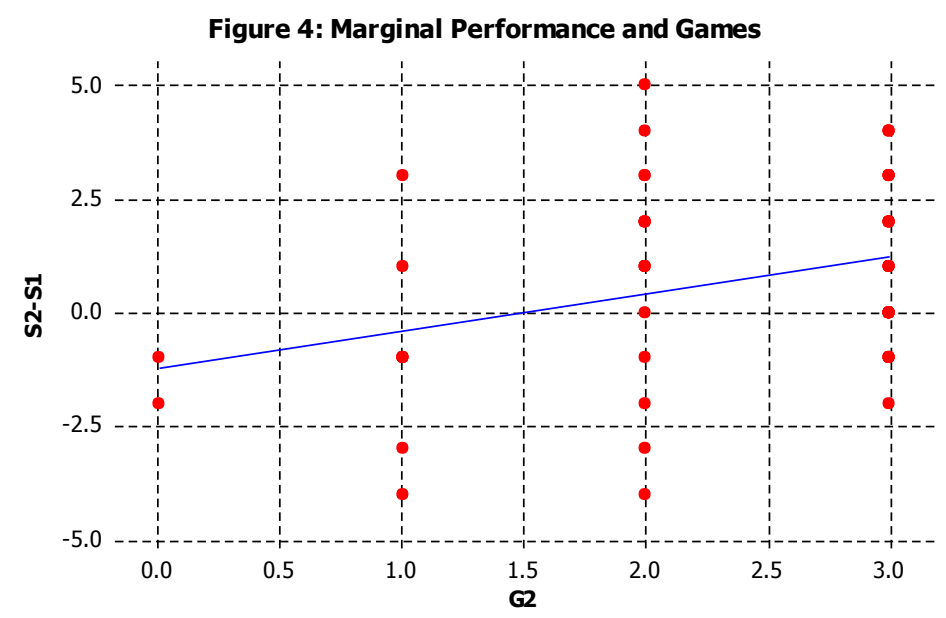

Table 7: Performance and Game attendance

\begin{tabular}{|c|c|c|c|}
\hline & \multicolumn{2}{|c|}{$\begin{array}{l}\text { System Equations: } \\
\text { Quiz Performances }\end{array}$} & \multirow{2}{*}{$\begin{array}{c}\text { Marginal } \\
\text { Performance }^{21}\end{array}$} \\
\hline Independent Variables & $\begin{array}{l}\text { Quiz 1 (S1) Score } \\
\text { (0-10 Scale) }\end{array}$ & $\begin{array}{l}\text { Quiz } 2 \text { (S2) Score } \\
\quad(0-10 \text { Scale })\end{array}$ & \\
\hline Constant & $\begin{array}{l}2.691 * * * \\
(1.034)\end{array}$ & $\begin{array}{l}3.453 * * * \\
(0.926)\end{array}$ & $\begin{array}{c}-1.225 * \\
(0.700)\end{array}$ \\
\hline G1: Game prior to quiz 1 & $\begin{array}{l}-0.158 \\
(0.638) \\
\end{array}$ & & \\
\hline G2: Games between two quizzes & & $\begin{array}{l}0.822 * * * \\
(0.232)\end{array}$ & $\begin{array}{l}0.824 * * * \\
(0.267)\end{array}$ \\
\hline Student's CGPA & $\begin{array}{l}1.148 * * * \\
(0.260)\end{array}$ & $\begin{array}{l}0.641 * * * \\
(0.242)\end{array}$ & \\
\hline Gender $($ Female $=1)$ & $\begin{array}{l}-0.957 * * \\
(0.442)\end{array}$ & $\begin{array}{l}-0.231 \\
(0.402)\end{array}$ & \\
\hline Resident ( Domestic $=1$ ) & $\begin{array}{c}0.668 \\
(0.502)\end{array}$ & $\begin{array}{l}-0.328 \\
(0.455)\end{array}$ & \\
\hline Program $(\mathrm{BBA}=1)$ & $\begin{array}{l}1.204 * * \\
(0.515)\end{array}$ & $\begin{array}{c}0.677 \\
(0.463)\end{array}$ & \\
\hline Mean of Dependent Variable & $6.500(\mathrm{C}+)$ & $7.167(\mathrm{~B}-)$ & 0.667 \\
\hline Adjusted R-Square & 0.323 & 0.348 & 0.094 \\
\hline System R-Square & & & \\
\hline Likelihood Ratio Test & & & \\
\hline Chi-Square Test for Heteroscedasticity & & & $4.485 * *$ \\
\hline
\end{tabular}

Notes: standard errors of the estimated coefficients are reported in parenthesis. Three $* * *$ indicates significance at the $1 \%$, ** indicates significance at the 5\%, * indicates significant at the $10 \%$ level.

In conclusion, we provide evidence from the same introductory microeconomics class that indicates evidence of a second dividend. The performance in quizzes was affected by the number of games students played after controlling for a number of factors such as the students cumulative GPA, gender, program of study and their international/domestic status. However, we also find support of Fels (1993) hypothesis that a single experiment will not affect student performance but using a number of experiments over a semester makes a difference in students' performance. $^{22}$ 


\section{CONCLUSION}

This paper presented evidence on the benefits that accrued to the instructor and to the students as a result of running numerous experimental games in a principles microeconomics class during the Fall 2006 semester. Most of the literature attempts to measure the benefits of experimental games that accrue to students in terms of performance enhancing grades. To the best of the author's knowledge there is no other study that examines the benefits that accrue to the instructor as a result of introducing classroom experimental games.

In order for experimental games to be an effective tool a necessary condition for success is the enhancement of the instructor's performance which in turn affects the students' motivation to study and perform better relative to the status quo method. Framed another way, experimental games may have less of an impact on students' understanding of material and performance in exams relative to the "chalk and talk" method if instructor's performance is not enhanced.

Despite the supporting evidence that experimental classroom games or other active learning methods yield positive results these have not been used in teaching economics in many universities and colleges. Watts and Becker (2005) show very low median and mean responses for usage of these methods over the last decade. This is puzzling and requires future research to identify reasons behind the observed excess inertia. However, research in this area has flourished as seen from the publications in many economic journals.

A question for future research is to identify whether it is the experimental games that result in an improvement in student performance which in turn leads to instructor's performance enhancement as measured by teaching evaluations. Alternatively, does causation operate the other way, namely that the instructor's enthusiasm and his improvement in teaching methods motivate students to perform better in the course.

\section{ABOUT THE AUTHOR}

Dr. Panagiotis Tsigaris is an Associate Professor of Economics at Thompson Rivers University (TRU), Kamloops, British Columbia, Canada, where he teaches introductory economics, statistics, environmental economics, and public finance. His diverse research interests span environmental economics, taxation, decisions under risk, and education. He has presented his research at numerous conferences around the world and published his research in a variety of peer-reviewed journals. In 2007 TRU awarded Dr. Tsigaris its Scholarly Merit and Teaching Excellence awards, the first time both awards have been won by a single faculty member in the same year.

\section{REFERENCES}

1. Ballard, C., and Johnson, M. 2005, Gender, Expectations, and Grades in Introductory Microeconomics at a US University, Feminist Economics, March, 11(1), pp. 95-122

2. Becker, W. E., 1997, Teaching Economics to Undergraduates, Journal of Economic Literature, 35, pp.1347-73

3. Becker, W., and Watts, M. 1996, Chalk and Talk: A National Survey on Teaching Undergraduate Economics, American Economic Review, May, 86(2), pp. 448-53

4. Becker, W. E. and Watts, M.. 2001, Teaching Methods in US Undergraduate Economics Courses, Journal of Economic Education, Summer, 32(3), pp. 269-79

5. Becker, W. E. and Watts, M., 2005, A Little More Than Chalk and Talk: Results from a Third National Survey of Teaching Methods in Undergraduate Economics Courses, December, Cheltenham, U.K.: Edward Elgar.

6. Brauer, J. and Delemeester, G., 2001. Games Economists Play: A Survey of Non-computerized ClassroomGames for College Economics, Journal of Economic Surveys, April, 15(2), pp. 221-36

7. Chamberlin, E. C.. 1948, An Experimental Imperfect Market, Journal of Political Economy, 56(2), pp. 95108. 
8. Chan, N, and P. Kennedy, 2002, Are Multiple Choice Exams Easier for Economics Students? A Comparison of Multiple Choice and "Equivalent” Constructed-Response Exam Questions. Southern Economic Journal, 68(4), pp. 957-971.

9. Dickie, M., 2006, Do Classroom Experiments Increase Learning in Introductory Microeconomics? Journal of Economic Education, Summer, 37(3), pp. 267-288.

10. Dickinson, D. L., A Bargaining Experiment to Motivate Discussion on Fairness. Journal of Economic Education. Spring, 33(2), pp. 136-151

11. Emerson, T. and Taylor, B., 2004, Comparing Student Achievement across Experimental and LectureOriented Sections of a Principles of Microeconomics Course, Southern Economic Journal, January, 70(3), pp. 672-93

12. Fels, R., 1993, This Is What I Do, and I Like It, Journal of Economic Education, Fall, 24(4), pp. 365-70

13. Greene, B., 1997, "Verbal Abilities, Gender, and the Introductory Economics Course: A New Look at an Old Assumption, Journal of Economic Education, Winter, 28(1), pp. 13-20.

14. Hazlett, D.. 1997, A Common Property Experiment with a Renewable Resource. Economic Inquiry, 35, October, pp. 858-861

15. Hemenway, D., R. Moore, and J. Whitney., 1987, The Oligopoly Game. Economic Inquiry, 25, Oct., pp. 727-730

16. Holt, C. A.. 1996, Classroom Games: Trading in a Pit Market, Journal of Economic Perspectives, Winter, 10(1), pp. 193-203

17. Holt, C. A.; 2003, Economic Science: An Experimental Approach for Teaching and Research, Southern Economic Journal, April, 69(4), pp. 755-71

18. Hoyt, G. M., P. L. Ryan, and R. G. Houston, Jr. 1999, The Paper River: A Demonstration of Externalities and Coase's Theorem. Journal of Economic Education. 30(2), Spring, pp. 141-147.

19. Neral, J., 1993, Widget Production in the Classroom. Classroom Expernomics, 2(1), Spring, pp. 7-8

20. Smith, V. L., 1962, An Experimental Study of Competitive Market Behaviour, Journal of Political Economy, 70, pp $165-79$

21. Sulock, J. M., 1990, The Free Rider and Voting Paradox 'Games. Journal of Economic Education, 21(1), Winter, pp. 65-69

22. Walstad, W.B., and D. Robson, 1997, Differential Item Functioning on Multiple-Choice Tests in Economics, Journal of Economic Education, Spring, pp. 155-171

23. Williams A. and J. Walker. 2001, Computerized Laboratory Exercises for Microeconomics Education: Three Applications Motivated by Experimental Economics, Journal of Economic Education, 24, 291-315.

\section{APPENDICES}

Appendix I: The syllabus of the course was as follows; the textbook used in the course was "Foundations of Microeconomics," by R. Bade, M. Parkin and B. Lyons, Addison Wesley. The course evaluation was based on the following structure:

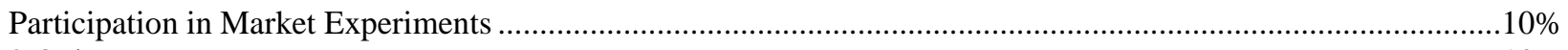

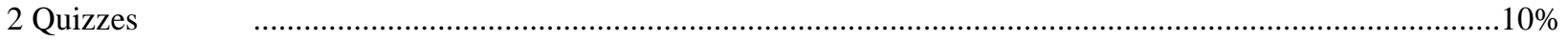

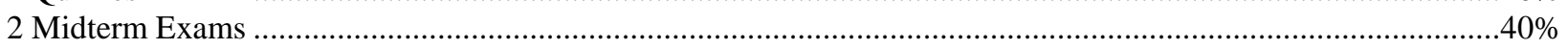

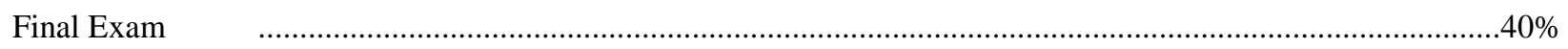

1. Introduction to Economics and the Canadian Economy, Chapter 1 and 2

2. Demand and Supply: The Pit Market Experiment, Chapter 4

Quiz 1

3. Elasticities of Demand and Supply, Chapter 5

Exam 1 
4. Efficiency and Fairness of Markets: The Ultimatum Experiment, Chapter 6

5. Government Influences on Markets, Chapter 7

6. Taxes, Chapter 8

7. Externalities: The Paper Plane Experiment, Chapter 9

8. Public Goods: The Free Rider Experiment, Chapter 10

Quiz 2

9. Common Resource Problem: The M\&M Experiment, Chapter 10

Exam 2

10. Consumer Choice and Demand, Chapter 11

11. Production and Cost, The Production of Widgets Experiment, Chapter 12

12. Perfect Competition, Chapter 13

13. Monopoly, Chapter 14

14. Monopolistic Competition and Oligopoly, The Oligopoly Game, Chapter 15

15. Regulation and Competition Law, Chapter 16

Final Exam

Appendix II: More comments from students on the classroom games:

- I enjoy the economics "games" - they assist in my understanding of concepts.

- $\quad$ Tries to engage students with learning activities (games)

- We play games in seminars and sometimes in class which are really helpful in understanding the course material.

- $\quad$ Experiments are an interesting way of showing us practical applications

- $\quad$ The games are relevant and fun

- Classroom experiments were great. They helped me to understand the concepts we were going over. They were all relevant to the course material

- $\quad$ I like to play the games. It has helped me grasp the material.

- $\quad$ Games he uses provide good examples of course material

- $\quad$ The games played during class are very helpful in explaining concepts of Economics. Entertaining way of learning.

Appendix III: Course Evaluations at TRU from 1993-2006. There are forty evaluations from first, second, third and forth year courses over the $1993-2006 .{ }^{23}$ The author was hired by TRU in August $1993 .{ }^{24}$ The courses where the instructor was evaluated are the following:

\begin{tabular}{|l|c|c|}
\hline Name of Course & Acrynom & Number of Courses \\
\hline Principles of Microeconomics & Econ 190 & 6 \\
\hline Principles of Macroeconomics & Econ 195 & 1 \\
\hline Introduction to Economics & Econ 111 & 6 \\
\hline Intermediate Macroeconomics & Econ 295 & 2 \\
\hline Managerial Economics & Buec 304 & 2 \\
\hline Statistics for Business and Economics II & Buec 233/333 & 5 \\
\hline Public Finance & Econ 350 \\
\hline International Financial Markets & Econ 410 & 3 \\
\hline Forecasting for Business and Economics & Buec 433 & 1 \\
\hline International Macroeconomics and Finance & Econ 456 \\
\hline
\end{tabular}




\footnotetext{
${ }^{1}$ The origin of classroom games, as a method of teaching, dates back to Chamberlin's lectures at Harvard. Chamberlin (1948) published the results of his classroom experiments with his doctoral students at Harvard. Vernon Smith (1962) continued the experiments. After a few decades, classroom games are now in the frontier of alternative active learning methods for economics. ${ }^{2}$ Student learning outcomes would be a better measure but impossible to capture.

${ }^{3}$ See Isely and Singh (2005) for a literature review in this area.

${ }^{4}$ In this paper we do not deal with this question. We examine teaching evaluations of this course relative to the historical past.

${ }^{5}$ Quizzes are available upon request.

${ }^{6}$ Fels states on page 369 "It may safely be predicted that a single experiment using one or two class hours would not make an important difference in how much students learn. (The same could be said of any use of one class hour, including cancelling it altogether.) Whether several experiments can make a difference probably depends on how well they reinforce other material in the course."

${ }^{7}$ The course syllabus is shown in appendix I.

${ }^{8}$ Other quotes are in appendix II

${ }^{9}$ Participation rate is lower because the game was not announced.

${ }^{10}$ Round two was played the following week.

${ }^{11}$ See appendix III for various courses taught by author.

${ }^{12}$ The experimental class is excluded from the above sample.

${ }^{13}$ The first quiz covered three chapters (Chapters 1,2 and 4 from Parkin, Bade and Lyons) worth of material, while the second quiz covered five chapters (Chapters 6,7,8,9 and some of 10) worth of material.

${ }^{14}$ A third explanation might be related to a learning curve. It could be possible that the games operate indirectly and affect the learning curve.

${ }^{15}$ For reference on the SUR method see Griffiths, Hill and Judge in their textbook "Learning and Practicing Econometrics".

${ }^{16}$ See Greene (1997), Waldstad and Robson (1997) who indicate that males perform better than females in fixed response tests, while Chan and Kennedy (1002) provide contrary evidence.

${ }^{17}$ CGPA is more relevant in the first quiz as seen from the higher coefficient. CGPA is the only significant variable affecting the expected participation rate in experiments. Students with higher CGPA have a higher participation rate on average.

${ }^{18}$ CGPA, gender, program of study and residency status were not significant in determining marginal performance in the two quizzes. Increased study time is an important determinant of marginal performance.

${ }^{19}$ The random error term captures other elements such as increased (decreased for others) study time allocated to second quiz relative to first quiz independent of the influence of games played. To the extent that that increased study time is an omitted variable and is most probably positively correlated with the relative game attendance the coefficient estimated above will be biased in the upward direction. Except if the students save time in acquiring economic knowledge as suggested by Brauer and Delemester (2001).

${ }^{20}$ We leave it for future research to study the effect of experimental games on study time and then study time on quiz performance.

${ }^{21}$ Column 4 was estimated using White's heteroscedasticity-consistent covariance matrix.

${ }^{22}$ Fels states on page 369 "It may safely be predicted that a single experiment using one or two class hours would not make an important difference in how much students learn. (The same could be said of any use of one class hour, including cancelling it altogether.) Whether several experiments can make a difference probably depends on how well they reinforce other material in the course."

${ }^{23}$ The instructor was in reduced load during the period 2002-2005 due to his added duties of being assigned to be the undergraduate business program advisor.

${ }^{24}$ Prior to this appointment the instructor was teaching at Concordia University on a part time basis while in the Ph.D. program.
} 


\section{NOTES}

